\title{
The Gap in the Law and the Border-Breaching Function of the Exception
}

Tracy McNulty

Cornell University

This paper evaluates the status and function of the border in the two polemics that bookend the long history of political theology: Paul's polemic against the Jewish law, and Carl Schmitt's critique of constitutional liberalism. Paul and Schmitt both challenge spatial notions of law that establish a boundary between an "inside" and an "outside" by topologizing "inside" and "outside" as continuous: through the "fulfillment of the law" in Paul, and through the strategy of sovereign exception in Schmitt. Schmitt even describes sovereignty as a "border concept," a Grenzbegriff: a concept that pertains to borderline cases, but perhaps at the same time a concept of the border, one that proposes a particular interpretation of the border and its logical function. The essay argues that Schmitt's contribution to the logical problem of law as border is to claim that the border need not be written, and that the sovereign exception is not of the order of a writing, but a "miracle" that is by nature unwritten and unwritable. The Hebraic tradition of law that is the object of Paul's polemic offers another way of considering the border, as the function of the written law. It conceives of law not as a normative representation of an existing situation, but as the delimination of a space or gap that may not be transgressed. While the fulfillment of the law and the sovereign exception bypass the limit implied in the law, offering a topological interpretation of the border as what integrates "inside" and "outside" into a new whole, the Hebraic law aligns the border with the logical function of negation. The essay approaches these different accounts of the border by way of Lacan's distinction between the imaginary and symbolic dimensions of law. The imaginary is the "incarnated" dimension of law, while the symbolic corresponds to the function of speech as a barrier or limit, and involves a spacing and negation, the introduction of a gap or emptiness that precludes anything like a "whole."

The relationship between political theology and the question of the border immediately brings to mind the two polemics that in many ways bookend the long history of political theology: Paul's polemic against the Jewish law, and Carl Schmitt's critique of constitutional liberalism. Paul and Schmitt both challenge spatial notions of law that establish a boundary between an "inside" and an "outside" by topologizing "inside" and "outside" as continuous: through the "fulfillment of the law" in Paul, and through the strategy of sovereign exception in Schmitt. In his mission to the Gentiles, Paul argues that the covenant with the Israelites does not define the borders of the kingdom of God; the "new covenant" (which is importantly not formalized in laws or practices) universalizes the promise by "including what was excluded," inscribing or integrating what was once "outside." Schmitt, on the other hand, suggests that the sovereign is the one who "decides on the exception," determining when the constitution needs to be suspended in its entirety in order to address an extreme threat that falls outside the bounds of ordinary legal prescriptions. The exception is thus defined by "unlimited authority," a breaching of the borders of the law that allows the sovereign to bring the exception under the authority 
of state power. Schmitt even describes sovereignty as a "border concept," a Grenzbegriff: a concept that pertains to borderline cases, but perhaps at the same time a concept of the border, one that proposes a particular interpretation of the border and its logical function.

The Hebraic tradition of law that is the object of Paul's polemic offers another way of considering the border, as the function of the written law. There, law is conceived not as a normative representation of an existing situation, but as the delimitation of a space or gap that may not be transgressed. While the fulfillment of the law and the sovereign exception bypass the limit implied in the law, offering a topological interpretation of the border as what integrates "inside" and "outside" into a new whole, the Hebraic law aligns the border with the logical function of negation. I will approach these different accounts of the border by way of Lacan's distinction between the imaginary and symbolic dimensions of law. The imaginary is the "incarnated" dimension of law, while the symbolic corresponds to the function of speech as a barrier or limit, and involves a spacing and negation, the introduction of a gap or emptiness that precludes anything like a "whole."

\section{The Unwriteable Border as Fulfillment of the Law}

In his 1922 text Political Theology, Schmitt observes that there is a "gap" in the law, which corresponds to the place of the exception. He asserts that the concept "legal order" is made out of two independent and autonomous elements, norm and decision, which together constitute the juristic sphere. In a normal situation, "the autonomous moment of the decision recedes to a minimum"; the existing law is simply applied. ${ }^{1}$ But the law cannot deal with a true exception, since an ordinary legal prescription is merely the representation of a general norm, an existing state of affairs; by definition, an exceptional situation is one that falls outside the norm (6). Since "the exception... is not codified in the existing legal order," it "can at best be characterized as a case of extreme peril, a danger to the existence of the state" (6).

In such an extreme case, the sovereign is defined as "he who decides on the exception" (5), intervening to act in the absence of any legal guideline. Initially Schmitt defined norm and decision as two autonomous elements of the legal order. Decision never entirely disappears, even when norms prevail; but in an exceptional situation, he now specifies that "the norm is destroyed" altogether (12). Decision alone comes to encompass the entirety of the juridical order, displacing the supposedly "autonomous" sphere of norm. ${ }^{2}$ In practical terms, the 
sovereign suspends the constitution in order to preserve the state. Nevertheless, Schmitt insists that the legal order does not disappear with the suspension of the constitution; instead, it is temporarily transferred to the person of the sovereign so that it may endure. The "legal order" is therefore something distinct from law itself; indeed, the primary function of the exceptional decision is to uphold the order of law by temporarily suspending the application of law. Once the exceptional situation is brought under his power, and order restored, the sovereign alone determines when the constitution can be reinstated. In Schmitt's words, "there exists no norm that is applicable to chaos. For a legal order to make sense, a normal situation must exist, and he is sovereign who definitely decides whether this normal situation actually exists" (I3).

The problem with the law is therefore a problem of representation: since the law does not create new situations, but merely "describes" a situation that is already in place, it is always secondary with respect to the legal order. Citing the words of Gerhard Anschütz, Schmitt writes: "There is not only a gap in the law, that is, in the text of the constitution, but moreover in law as a whole, which can in no way be filled by juristic conceptual operations. Here is where public law stops" (I5, my emphases). Schmitt's initial gloss of this "gap in the law" considers the law as the representation of a norm, one that can either be applied to a given object or situation or found to be inapplicable, as in the exceptional case. But when he follows Anschütz in claiming that there is a gap not only in the text of the constitution, but "in law as a whole," Schmitt extends his critique from the problem of representation or naming (the gap between what the law foresees and the exceptional case) to a more structural problem. The law as such, the whole of law, contains a gap: one that "can in no way be filled." Or, more accurately, the gap structurally internal to law means that there is no such thing as a "whole of law," because the law "as a whole" is structured by a gap that prevents it from achieving totalization or closure. To the critique of law as secondary representation he therefore adds an implicit critique of law as limit, as what suspends or puts a stop to juridical authority.

Unlike Anschütz, however, Schmitt asserts that the gap in the law can indeed be filled: the gap not only in the text of the constitution, but also in the "law as a whole." The decision on the exception fills this gap by substituting the embodied power of the sovereign for the suspension or gap internal to the law. The sovereign is the one who is not limited by the limit, and who therefore suspends the suspension introduced by the law. In Schmitt's words, 
What characterizes an exception is principally unlimited authority, which means the suspension of the entire existing order. In such a situation it is clear that the state remains, whereas law recedes. Because the exception is different from anarchy and chaos, order in the juristic sense still prevails, even if it is not of the ordinary kind. The existence of the state is undoubted proof of its superiority over the validity of the legal norm. The decision frees itself from all normative ties and becomes in the true sense absolute. The state suspends the law in the exception on the basis of its right of self-preservation, as one would say. (12, my emphases)

When Schmitt writes "the state remains, whereas law recedes," he makes clear that the "order of law" is really an order without law, which differs from law in that it excludes the "gap." The basic tension is between law as the mediation of an authority-an authority it simultaneously represents and limits - and the unmediated character of the sovereign decision that "embodies" law, allowing the legal order to coincide with authority or power. According to Schmitt, "The exception reveals most clearly the essence of the state's authority. The decision parts here from the legal norm, and (to formulate it paradoxically) authority proves that to produce law it need not be based on law" (13).

Let us now return to Schmitt's initial definition of the sovereign as "he who decides on the exception" (5), and the peculiar understanding of the border it advances. Schmitt writes, Only this definition can do justice to a borderline concept [Grenzbegriff]. Contrary to the imprecise terminology that is found in popular literature, a borderline concept is not a vague concept, but one pertaining to the outermost sphere. This definition of sovereignty must therefore be associated with a borderline case and not with routine. It will soon become clear that the exception... refer[s] to a general concept in the theory of the state, and not merely to a construct applied to any emergency decree or state of siege. (5)

Sovereignty relates to "borderline cases," those at the edge of the law's jurisdiction. But at the same time, sovereignty is itself a border case, since the sovereign is neither internal nor external to the legal order. To describe his place, Schmitt resorts to an oxymoronic formulation: 
"Although the sovereign stands outside [steht außerhalb] of the normally valid juridical order, he nevertheless belongs [gehört] to it, for it is he who must decide whether the constitution needs to be suspended in its entirety" (7, translation modified). When we try to represent logically the different moments or positions implied in this figure, it becomes clear that three different understandings of the border are in play.

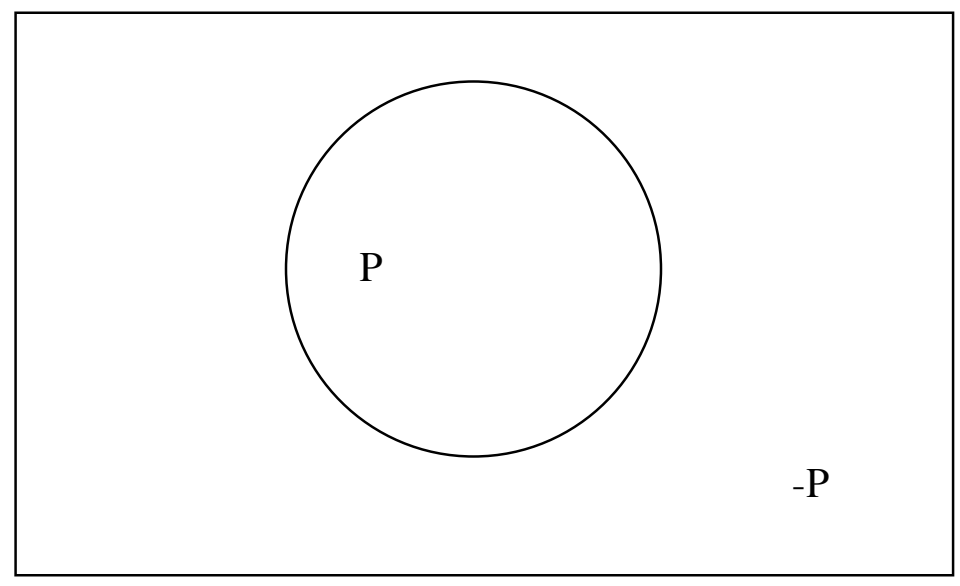

\section{Diagram I: Classical Logic}

The first diagram might describe the simple case of "belonging to" the juridical order. In the binary rules of classical logic, either a thing is or it is not. $\mathrm{P}$ and - $\mathrm{P}$ are complementary and mutually exclusive, meaning that together they cover all possible cases. This is the "law of the excluded middle," which excludes any consideration of the border case. The border is simply disregarded. In the terms of Schmitt's argument, $\mathrm{P}$ is the "juridical order" or nomos, and -P is the anomic situation that threatens its existence. The sovereign belongs to the juridical order.

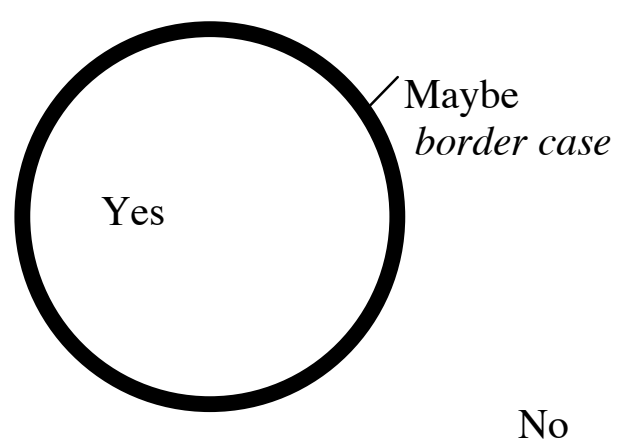

Diagram II: Constructive Logic 
In the second diagram, which corresponds to the case of "standing outside" the juridical order, the border has its own status. This is constructive logic, where the "law of the excluded middle" is not a theorem. $\mathrm{P}$ and $-\mathrm{P}$ do not exhaust all possibilities, because a new "boundary case" arises which is written as a border. If we define the two regions that were previously mutually exclusive as "yes" and "no," the border would correspond to a new possibility: "maybe” or "we don't know yet." In Schmitt's terms, the definition of sovereignty is associated with a "borderline case;" the decision on the exception does not belong to the "normally valid juridical order” (“yes”), but represents a distinct sphere of operation.

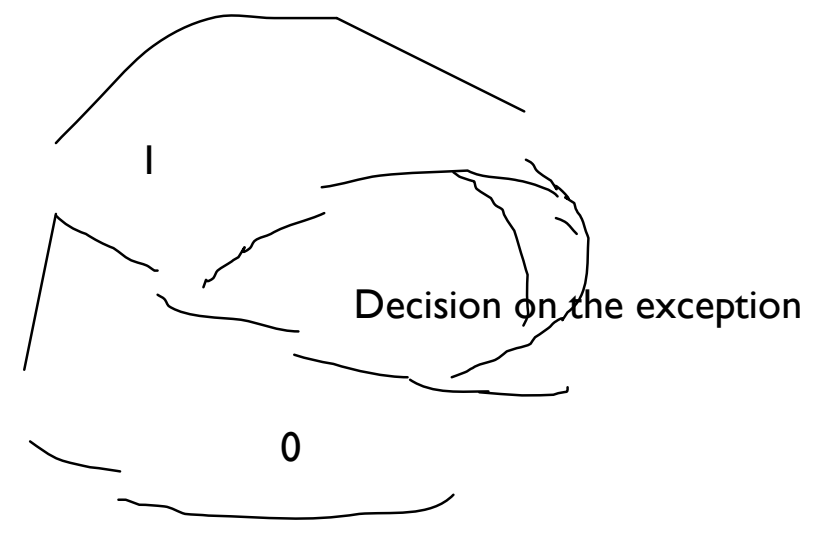

Diagram III: Topology

The third diagram corresponds to the figure of "standing outside, yet belonging." The sovereign decides whether the constitution needs to be suspended in its entirety, in order to bring the anomic situation under the control of the legal order, the state. In so doing, he inaugurates an exceptional situation defined by "unlimited authority," in which "authority proves that to make law it need not be based on law." In this case it is no longer possible to distinguish between "inside" and "outside," "yes" and "no," nomos or anomie. If we were to evoke it topologically, for example as a möbius strip, the border would become a twisted, twosided circular band, making inside (I) and outside (0) continuous. With respect to the first two diagrams, the border is neither a mere line of demarcation (as in \#I) nor a distinct case (as in \#2), but the articulation and integration of previously distinct spheres (the juridical order and the exception). The sovereign embodies the state, and there is nothing outside his authority. 
My point in presenting these different treatments of the border is to show that while each of these cases can be written logically, there is no way to write the movement from one to the next: each implies an interpretation of the border that is incompatible with the others. The incompatibility inheres in their different treatments of negation. In the first case, $P$ negates -P and vice versa. In the second case, "maybe" does not negate "yes" or "no," even if it is not reducible to either case; but "yes" and "no" are still mutually exclusive. In the third case, this possibility of negation is eliminated altogether. It's an understanding of the border from which the notion of the limit has been excluded. (In other words, although you can use a line to draw a möbius strip, this writing does not have the same logical function as in the first two cases: it merely allows for an imaginary representation of a figure that cannot be "written" at all, insofar as writing is aligned logically with the limit or negation.)

With respect to Schmitt, the upshot is that it's impossible to write the place of the act, the decision that articulates these different articulations of the legal order. In his claim that sovereignty is a "border concept," Schmitt's contribution to the logical problem of the border is thus to claim that the border is not of the order of a writing, but a "miracle" that is by nature unwritten and unwritable (if not, indeed, antinomial to writing). The border is now an "act," an act whose function is to close the gap in the law by transforming the set it intervenes in: the juridical order defined by norms becomes the "legal order" embodied by the sovereign. (In the third diagram, the space that corresponded to "yes" in diagram II, the space of the "normally valid legal order" or law, is in the process of being "destroyed" by the exception, such that the border representing the decision comes to encompass the whole juridical order.) While the law both erects boundaries and is itself bound by a writing, neither condition applies to the juridical order. The result is that not only the decision, but also the juridical order itself, cannot be written in logic.

This is what Schmitt aptly terms the "miracle" of the theologico-political, in his famous claim that "the exception in jurisprudence is analogous to the miracle in theology" (36). The model for the sovereign's "direct intervention in a legal order" is the "transgression of the laws of nature through an exception brought about by direct intervention, as is found in the idea of a miracle" (36). When Schmitt claims that "all significant concepts of the modern theory of the state are secularized theological concepts" (36), he reveals his debt not only to the early modern Catholic theologians he discusses at some length, but more profoundly to the political 
theology of Paul. Most immediately, his conception of the state as unbounded or unwritable recalls Paul's famous distinction between the two Jerusalems: the "Jerusalem of the flesh," who lives in slavery to the law, and the unbounded "Jerusalem above," born free through the promise (Galatians 4:22-3I). ${ }^{4}$

But more specifically, Schmitt's argument reproduces almost exactly Paul's interpretation of the "fulfillment of the law" introduced by Jesus. This fulfillment takes a paradoxical dual form, which anticipates the fraught topology of the exception. On the one hand Jesus realizes or completes the law, bringing it to fruition by making good on its promises and animating its living spirit; but on the other he voids the law, rendering it obsolete, in much the same way that the fulfillment of a legal contract renders it null and void. As the ultimate example of the sovereign exception, Christ is the model for the paradoxical logic of "being outside, yet belonging" that for Schmitt defines the sovereign's place with respect to the juridical order: because he embodies the law, he can suspend the law.

Importantly, Schmitt takes from Paul not only a theory of sovereign action, but also a critique of the written law as a mediating representation. Paul's famous polemic against the Jewish law is structured by a distinction between two orders of law: the "law of God" and the "law of sin." The first is associated with the intelligible "spirit" of the law, which is "written in the heart," and the second with the prescriptive "letter" of the law, which compromises or corrupts the first by binding it to a particular representation and consigning it to written form. His polemic is directed at not just any law, but at one of the commandments of the Hebrew Decalogue. In his letter to the Romans, Paul writes:

$\ldots$ if it had not been for the law, I should not have known sin. I should not have known what it is to covet if the law had not said, "You shall not covet." But sin, finding opportunity in the commandment, wrought in me all kinds of covetousness. Apart from the law sin lies dead. I was once alive apart from the law, but when the commandment came, sin revived and I died; the very commandment which promised life proved to be death to me. For sin, finding opportunity in the commandment, deceived me and by it killed me... So I find it to be a law that when I want to do right, evil lies close at hand. For I delight in the law of God, in my inmost self, but I see in my members another law at war with the law of my mind 
and making me captive to the law of sin which dwells in my members.

(Romans 7:7-I I, 21-23)

In prohibiting, the law incites transgression by representing to the imagination an object of desire. ${ }^{5}$ The commandment is thus the vehicle through which sin and death insinuate themselves into the Jewish law, perverting or derailing our quest for the law of God.

Paul's solution is to bypass the law, to bypass representation, and perhaps even language itself. Law as we know it - the prescriptive "letter" of the Jewish law-must be subordinated to and sublated by the law of the spirit: ${ }^{6}$

my brethren, you have died to the law through the body of Christ, so that you may belong to another, to him who has been raised from the dead in order that we may bear fruit for God. While we were living in the flesh, our sinful passions, aroused by the law, were at work in our members to bear fruit for death. But now we are discharged from the law, dead to that which held us captive, so that we serve not under the old written code but in the new life of the Spirit. (Romans 7:4-6)

As the living embodiment of God's law, Christ is the "sovereign exception" who upholds the spirit of the law by "fulfilling" - and so rendering obsolete-its written form. In the same way, the result of the sovereign exception theorized by Schmitt is that we no longer obey the law, but the sovereign who introduces a new order through its suspension. In both cases the attempt to extend the order of the nomos takes the paradoxical form of a fulfillment or eradication of the law as such, in favor of the "order of law" embodied by the sovereign himself.

This argument reveals something further about the nature of the "gap in the law" bemoaned by Schmitt, which the decision is supposed to fill. The gap in the law is a problem internal to the law as representation, which does not simply fail to anticipate anomic situations, but structurally stands in the way of fulfillment because it introduces a detour or distance with respect to the Good. As Paul puts it, "I find it to be a law that when I want to do right, evil lies close at hand"; this is because "the commandment that promised life proved to be death to me." In other words, the commandment that promised access to the Good deceived me with representations that derailed my quest, leading me astray from my aim.

In Schmitt's terms, the law binds us to a "normal" situation: it has no transcendent dimension or capacity for "miracle." Only the sovereign exception can inscribe the good within 
the juristic sphere, by suspending the law that introduces a gap between the legal order and the general good to which everyone aspires:

Everyone agrees that whenever antagonisms appear within a state, every party wants the general good-therein resides after all the bellum omnium contra omnes. But sovereignty (and thus the state itself) resides in deciding this controversy, that is, in determining definitively what constitutes public order and security, in determining when they are disturbed, and so on. $(9)^{7}$

The decision is what closes the "gap" between representation and the good, bringing it within reach. Importantly, though, Schmitt makes clear that "the good" has no specific content: not even something as abstract as "equal opportunity" or "life, liberty, and the pursuit of happiness." In deciding on the good, the sovereign simply determines "what constitutes public order and security." This suggests that the "general good" is really just a synonym for the preservation of the state, whose continued existence is secured by bringing under its power the forces that would seek to limit its authority through violence or other subversive actions. ${ }^{8}$

Schmitt's contemporary Walter Benjamin offers what may still be the most trenchant critique of this argument, when he questions the form (or lack of form) this "good" takes. In his Theses on the Concept of History, Benjamin writes: "the tradition of the oppressed teaches us that the 'state of exception' in which we live is the rule. We must attain to a concept of history that accords with this fact. Then we will clearly see that it is our task to bring about a real state of exception, to improve our position in the struggle against fascism." 9 In suggesting that the state of exception has become the rule, Benjamin contests Schmitt's account of the exception by suggesting that the sovereign's suspension of the law may not be temporary, as Schmitt claims, but endure indefinitely. This is his assessment of the state of exception in the Weimar period, where the state of emergency declared by the Nazi Reich was never repealed. ${ }^{10}$ But I would suggest that Benjamin's notion of a "state of exception that becomes the rule" is not specific to modern totalitarianism, but could even function as a possible definition of the kingdom of Christ, within Paul's understanding of the fulfillment of the law. " Since for Paul the law impedes access to the Good, it follows that the fulfillment of the law must involve a permanent suspension: one that "becomes the rule." 
What would a state of exception become the rule look like? Commenting Benjamin's remarks, Giorgio Agamben proposes that in such a case, "every fiction of a nexus between violence and law disappears;" what remains is "nothing but a zone of anomie, in which violence works without juridical clothing of any kind." 12 Schmitt himself specifies, "the state intervenes everywhere," acting with "unlimited authority"13.

There always exists the same inexplicable identity: lawgiver, executive power, police, pardoner, welfare institution. Thus to an observer who takes the trouble to look at the total picture of contemporary jurisprudence, there appears a huge cloak-and-dagger drama, in which the state acts in many disguises but always as the same invisible person. The "omnipotence" of the modern lawgiver... is not only linguistically derived from theology. (38)

Even in Paul, for whom the fulfillment of the law ushers in the reign of the holy "law of the spirit," this state of exception tends to sound uncannily like a police state. This is because the "spirit of the law" takes the form of an internal "voice of conscience" that is distinctly superegoic in character, and fundamentally opposed to the "letter" as limit. The result of Paul's logic is that the subject is not only "freed" from law in its prescriptions, but delivered over to another authority: as he tells the Romans, "you have died to the law through the body of Christ, so that you may belong to another." What Agamben describes as an "anomic zone where violence works without juridical clothing of any kind" could be assimilated to the unarticulated, invisible "force of law" that animates Christianity. The Christian is a "law unto himself," but only insofar as he is possessed by a "force of law" that works without "juridical clothing." In Paul's words, “Christ judges the secret thoughts of all” (Romans 2:I), bypassing speech in order to penetrate the subject's consciousness.

\section{The Gap in the Law and the Function of the Symbolic}

In his seminar The Ethics of Psychoanalysis, Jacques Lacan offers a different approach to the problem of the Sovereign Good, which attempts to account for the superegoic character of any ethics that seeks to bypass the function of the law. He begins with Freud's account of the incest prohibition that excludes the mother as a possible object of sexual fulfillment. What it reveals, says Lacan, is that "the Sovereign Good, which is das Ding, which is the mother, is also 
the object of incest, is a forbidden good, and there is no other good. Such is the foundation of the moral law as turned on its head by Freud." ${ }^{4}$ The incest prohibition reveals that the law does not lead to the Good. Instead, its function is to lead us away from this Good, to debar it or put it under erasure. The mother is marked as the Good that one must not have, because to possess it would mean the effacement of the subject, its absorption by the Other.

Lacan defines das Ding, "the Thing," as the guiding pole of our desire. At the level of unconscious experience, das Ding presents itself as that which "makes the law" (73), but a "capricious and arbitrary law... in which the subject receives no guarantee from anywhere, a law in relation to which he has no [security]" (73). This is the law of the death drive, of the repetition compulsion that causes the subject to pursue its pleasure on the very paths that have the potential to cause him the most pain.

While das Ding is experienced as "making the law" at the level of the unconscious, driving the subject in ways he cannot control, the role of the law as prohibition is to limit its insistence. Its function can be understood with respect to what Freud calls the pleasure principle, the psychic regulatory mechanism that maintains equilibrium by keeping the Thing at a distance. Lacan sums up its function in a paradoxical formula: "the pleasure principle governs the search for the object and imposes the detours which maintain the distance in relation to its end" (58). From this perspective, "das Ding is at the center only in the sense that it is excluded" (7I). It is the horizon of the pleasure principle, its "aim," and yet an aim that it can only approach indirectly, by detouring around it. What we call "pleasure" is really nothing more than a detour away from the ultimate "fulfillment," the Thing that cannot be born and that, when the subject gets too close, is experienced as the most unbearable pain. This is why Lacan says of das Ding that "if he is to follow the path of his pleasure, man must go around it" (95). ${ }^{15}$

The signifier of the law functions to erect a barrier against das Ding, in two ways: it holds it at a distance by introducing a gap or space between the subject and his good, and it proposes representations that evoke das Ding indirectly or in distorted form. Lacan develops the first point through an account of the creation ex nihilo. Like the potter who fashions a vase, the mythical creator starts with a hole (12I). In the biblical myth, the first act of creation is really a negation, the division of the primordial unity into earth and sky, land and water: a series of cuts or oppositions that create a space where something is missing, a space in which life 
becomes possible. What it demonstrates is that "the fashioning of the signifier and the introduction of a gap or a hole in the real are identical" (I2I).

Lacan famously claims "nothing is missing from the real." But if the real can be defined most simply as an uninterrupted unity or presence, this means not only that the real is complete, but that nothing is missing from the real: the real includes everything except the nothing. In other words, what is missing from the real is the "no," the barrier or prohibition that opens up a space for the subject by negating some part of the real, interrupting this original unity: for example, the paternal prohibition that separates the original dyad of mother and child, allowing the child to pursue an independent life of desire. Lacan defines das Ding as "that which, in the real, suffers from the signifier" (I I8). But this "suffering" is necessary, since if it doesn't suffer we do. ${ }^{16}$

The operation of the pleasure principle is therefore associated with a certain comfort or well-being. But Lacan argues that when the moral law introduces the Good as its aim, it disrupts this sense of well-being (72-3). The remark occurs in a commentary on the revolution in ethics introduced by Paul, and developed by Kant. But I would argue that it applies not only to Paul's understanding of the "fulfillment of the law," but to Schmitt's account of the exception. For Schmitt, "nothing is missing" is really the ideal of the legal order embodied by the sovereign: the decision on the exception includes what was excluded, closing the gap in the law. ${ }^{17}$ Both authors could be understood as collapsing the defenses introduced by the law, attempting to reconnect the order of the law to its excluded center. ${ }^{18}$ What Benjamin describes as a "state of exception become the rule" is really the intrusion of the real associated with the breaching of the law as barrier, the collapsing of this symbolic space. ${ }^{19}$

Lacan's understanding of law as introducing a gap or distance with respect to das Ding introduces another way of thinking about representation, as well. He argues that law on the model of the pleasure principle makes use of representation to "evoke the good das Ding brings with it" (72), but on the condition that it be evoked only indirectly or in distorted form. ${ }^{20}$ In the example of the incest prohibition, the law not only proposes the mother as forbidden Good as a representation of das Ding, but introduces a further detour with respect to its aim by proposing women who are like the mother as substitutes for the mother herself. In Lacan's words, "Freud's use of the good can be summed up in the notion that it keeps us a long way from our jouissance," from the ultimate fulfillment represented by das Ding as the Good (185). 
With respect to the distinction we find in Paul and Schmitt between the written law as mediation and the embodied law of the sovereign, we could say that Lacan is really proposing a different understanding of the law as representation, whose function is symbolic rather than imaginary. It emphasizes a different kind of distance than the one implied in description or imitation, as a greater or lesser resemblance to the thing represented. ${ }^{21}$

Paradoxically, Lacan will also identify this symbolic function of the law with the lie. But whereas Paul conceives of the written law as a deceitful (mis-)representation of the Good, Lacan suggests that the law consists in "lying about evil." Because the subject cannot stand the extreme good that das Ding may bring him, he must defend himself against it; human defense, says Lacan, "takes place by means of something that has a name, which is... lying about evil. At the level of the unconscious, the subject lies. And this lie is his way of telling the truth of the matter" (73). What then is meant by "lying about evil," and how does it differ from the modality of lying indicted by Paul?

Lacan clarifies it through a discussion of one of Freud's patients, a woman who has a phobia about going into stores because she's afraid people will make fun of her clothes. He summarizes her case in the following terms:

Everything is related to an early memory. At the age of twelve she went into a store and the shop assistants apparently laughed at her clothes. One of them attracted her and even stirred her in some way in her emerging puberty. Behind that we find a causal memory, that of an act of aggression she suffered in a shop at the hands of a Greis. The French translation... says "shopkeeper"-but an old fogey is involved, an elderly man, who pinched her under her dress in a very direct manner. This memory thus echoes the idea of a sexual attraction experienced in the other.

All that remains in the symptom is attached to the clothes, to the mockery of her clothes. But the path of truth is suggested in a masked form, in the deceiving Vorstellung of her clothes. In an opaque way, there is an allusion to something that did not happen on the occasion of the first memory, but on the second. Something that wasn't apprehended in 
the beginning is apprehended retroactively, by means of the deceitful transformation. (74)

The "deceitful Vorstellung" of the clothes is a "lie," a displacement or distortion of what is really at stake; but it also leads to it, indirectly. ${ }^{22}$ In the terms of Lacan's earlier argument, representation introduces a distance with respect to das Ding, and so "lies about evil," but in lying it also allows it to be represented indirectly, by means of detours that maintain it at a certain distance.

The choice of clothing as a "deceitful Vorstellung" is further important in that the mode of representation is metonymic, and not metaphoric. In other words, the substitution is commanded by a spatial logic of contiguity, rather than a logic of resemblance or similarity. It recalls the logic of the fetish, a representation that functions as a metonymic substitute for the unbearable truth of the mother's castration. Analyzing the frequency with which feminine underclothes occur as fetishes, Freud suggests that the choice of the fetish is determined not by resemblance to the expected organ, but by spatial contiguity: it is the last thing the child sees before discovering the lack of the mother's penis. The fetish is therefore a representation without an imitative function: not only because it represents something that doesn't even exist, that is of the order of a hallucination, but also because it stands in for the unthinkable truth of castration. Its function is to clothe the unrepresentable in a representation. ${ }^{23}$

While Paul and Lacan are in agreement that the law "lies about evil," they interpret this lie in two different ways, which bring into relief a fundamental distinction between the imaginary or "representational" function of law (where the law attempts to represent the Good, but always falls short of its goal) and the symbolic or "barrier" function. Where Paul maintains that the law as representation is inevitably a mis-representation, a superficial or misleading depiction of an ideal or truth, Lacan suggests that the "failure" of representation is part of the point, since the function of law on the model of the pleasure principle is to represent inaccurately or in distorted form, and thereby maintain at a distance. ${ }^{24}$ In other words, he asserts that the lie has a symbolic function, as well as an imaginary one. ${ }^{25}$ It does not merely conjure up a (false) image, but introduces a space that was not there before.

The interdependence of these two modalities of "lying" is nowhere more obvious than in the Hebrew Decalogue, which Lacan reads as an exemplary articulation of the structure of 
law. The Decalogue is divided into two tablets, whose commandments are often broadly interpreted as concerning God and the Neighbor, respectively.

\section{Commandments concerning God Commandments concerning the Neighbor}

$\begin{array}{ll}\text { I. no other gods } & \text { 6. no murder }\end{array}$

2. no idols or images 7. no adultery

3. no misuse of the divine name $\quad$ 8. no theft

4. remember the Sabbath day 9. no bearing false witness

5. honor the mother and father 10. no coveting

The first tablet concerns the Sovereign Good as das Ding, as something beyond representation that cannot be depicted or named. The first three commandments - against worshipping other deities, making images of God, or misusing the divine name-evoke the field of das Ding in relation to God. Together they establish that the Good that is beyond representation is also a deadly Good, and that we must keep our distance from it. As the book of Exodus never tires of reminding us, to look on the face of God is to die. But while the sublime God of terrible power may be the ultimate representative of das Ding, something similar is at stake in the commandment to honor the mother and father. Linking the veneration of the parents to the worship of God, it recalls Lacan's earlier argument concerning the mother as das Ding, the forbidden Good named by the incest prohibition. Both must be worshipped or "honored" from an appropriate distance.

In identifying God with a space that cannot be breached or transgressed, the Mosaic law does not simply establish the parameters of religious observance. It articulates something fundamental about the symbolic structure of the law, whose violent spacing of the real undercuts the fantasy of a possible embodiment or incarnation of the Good implicit in Paul's and Schmitt's different accounts of the exception. In early Jewish ritual practice this negative space is given form in the Holy of Holies, the innermost sanctum of the Israelite tabernacle. It is associated with the deity not as the site of his manifestation or presence, but as a space that must not be entered on pain of death, a "holy hole."

This logic is nowhere better expressed than in the fourth commandment: 
Remember the Sabbath day, and keep it holy. Six days you shall labor and do all your work. But the seventh day is a Sabbath to the LORD your God; you shall not do any work-you, your son or your daughter, your male or female slave, your livestock, or the alien resident in your towns. For in six days the LORD made heaven and earth, the sea, and all that is in them, but rested the seventh day; therefore the LORD blessed the Sabbath day and consecrated it. (Exodus 20:8-II)

According to Lacan, "that suspension, that emptiness, clearly introduces into human life the sign of a gap, a beyond relative to every law of utility" $(8 \mathrm{I})$. What it remembers or sanctifies is God's creation of the world, which paradoxically concludes with the insertion of a gap. In a rich gloss of Lacan's reading, Julia Lupton and Ken Reinhard write that

God completes the world by subtracting something from it, namely his own activity... The sublime emptiness of the seventh day marks the close of the process of creation ex nihilo that began with God's first utterance, an act, the Kabbalah argues, that required God to diminish himself, to decomplete his own fullness in order to make room for the world. ${ }^{26}$

God withdraws to create a place where "something is missing," namely his own full presence. In this way, the commandment links the emergence of the human subject to the negation of the fullness of the real, the unmediated presence of das Ding. In the words of Lupton and Reinhard, "the subject of religion... only emerges in the decompletion of the symbolic universe, through the positive addition to the cosmos of an instance of negation." 27

Turning to the second tablet, we might say that the commandments concerning the neighbor propose substitutions for what is at stake in the first tablet, "translating" das Ding into a different order of "things": the objects and interpersonal relations regulated by the juridical sphere. Lacan notes that German contains two words for the thing, both of which relate to the juridical context: die Sache and das Ding. Die Sache is "the thing that is juridically questioned," which marks "the transition to the symbolic order of a conflict between men" (44). In Freud's usage, die Sache is intimately linked to representation in speech: whence the close connection in his theory of the unconscious between Sachvorstellung, the representation of things, and Wortvorstellung, the representation of words. But while "Sache and Wort... form a couple, das Ding is found somewhere else" (45). It is "the true secret" (46), the Thing at stake in the law 
only in the sense that it is excluded by it (7I). At the level of what it names or represents, the law is concerned with the objects at stake in conflicts between men; but these objects assume their true significance only in their secret relation to das Ding, the excluded center around which the law circulates.

Drawing on this analysis, we might say that the second tablet concerns goods as substitutes for the Good, recalling the function of the "deceiving Vorstellung" analyzed by Lacan. The law "lies about evil," and this is its chief virtue: it proposes objects that "represent" or substitute for das Ding, thereby keeping it at a distance. (Now it is a matter of women, slaves, and donkeys as mere commodities or things, and not the Thing.) In relation to the first tablet, we could say that the law provides us with representations, but only on the condition that the depiction of the Good be strictly outlawed: something else, some other thing, must be represented in its place.

Lacan illustrates his point using the same example commented by Paul - the commandment against coveting the neighbor's goods-but with a different conclusion. In the wording of the commandment, says Lacan, "the covetousness that is in question is not addressed to anything that I might desire but to a thing that is my neighbor's Thing" (Ethics 83). In other words, the subject's Thing is evoked in displaced form, metonymically, through reference to the neighbor's wife and goods. What the commandment is really saying is that I must not covet my own Thing, that I must keep it at a distance; but it expresses this by attributing that Thing to the neighbor. (This suggests that the fifth and tenth commandments might together express what is at stake in the incest prohibition: the neighbor's forbidden wife both partakes of the allure of the mother as das Ding, and also holds it at a distance by means of displacement.) In the "deceitful Vorstellung" of the neighbor as a metonymic substitute for the self, the moral law "lies about evil" by suggesting that the Thing that must be avoided is my neighbor's Thing, and that it is a question of protecting the neighbor from my aggression. In this example, the "lie" consists not in distorting or misrepresenting, but in holding at a distance; in other words, it represents the thing, but in such a way as to put it over there.

In conceiving of the law as the delimitation of a space that must not be breached, the Mosaic law reveals something fundamental about the function of speech with regard to the deadly Good at stake in das Ding, and thus about the structural function of the written laws as laws of language. Lacan says of the ten commandments "whether or not we obey them, we still 
cannot help hearing them-in their indestructible character they prove to be the very laws of speech" (I74). This is because the condition of speech is "distance between the subject and das Ding" (69).

The ninth commandment, against bearing false witness, is related to this. It concerns testimony, the use of speech in the juridical situation. Noting that the word "testimony" derives from the Latin testes, Lacan implies that testimony always concerns what is most intimately at stake for the one who speaks, regardless of what he's talking about. Even when he's speaking about the neighbor, in other words, it's always his own balls that are on the line. The earlier discussion of the law as "lying about evil" also allows for a more ironic reading of the commandment: don't give false testimony against the neighbor, but by all means lie about das Ding: in part by pretending that it's the neighbor you're really talking about.

Taken together, the first and second tablets delineate the two functions of the signifier: negation and representation. The first tablet involves the introduction of a gap where "something is missing," a violent spacing that disrupts the unity of the real, causing it to "suffer." The second tablet concerns speech as representation or evocation: on the one hand the "imaginary" function of the law indicted by Paul (where the law conjures up objects that incite transgression, deceiving us with images), and on the other the function of representing indirectly, by substituting goods for the Good.

This is all very well, you might be saying, but what does it have to do with Schmitt? One could reasonably object to everything l've just said that Lacan is talking specifically about the function of the moral law, which concerns the problem of ethics in its relation to the Good, whereas Schmitt is dealing with the more concrete concerns of constitutional law and of the juridical sphere as such. But what the logic of the ten commandments makes clear is that the "everyday" law that adjudicates disputes between persons and things, assigning responsibilities and regulating conduct, cannot be considered in isolation from the structural function of the law as the introduction of a space or gap. In terms of Hebraic law, it makes clear that the second tablet, which anticipates and in some ways condenses the six hundred and thirteen specific laws that follow, cannot be severed from the first. This insight is the specific innovation of the Mosaic law, a heritage that has been sidelined or forgotten as the commandment tradition has been integrated into Western jurisprudence. Even as the commandments of the 
second tablet become the foundation of property and tort law, the commandments of the first tablet have largely been abandoned by subsequent legal traditions.

This forgetting really begins with Paul himself, who directs his polemic at one of the commandments from the second tablet, but never confronts the logic implied in the first. His critique of the law represents a turning point with respect to this understanding of law as barrier, since it supposes that the point is to get to the aim, to accede directly to the Good. In the letter to the Galatians, he argues that to live under the law is to live with the impossibility of ever fulfilling the law, since one would have to fulfill the precepts in their entirety, something the flesh can never do (Galatians 3:10). ${ }^{28}$ In essence, Paul's conclusion is that if we aspire to reach the Good by way of the law, we will never get there.

In insisting on the logic of the first tablet, Lacan's analysis of the Hebraic law does not so much dispute Paul's conclusion as affirm it. When Paul complains that the law introduces a detour with respect to the Good, Lacan's response is to say, in effect: Exactly! That's what the law is for! We aren't trying to use the law to get to the Good, but to protect us from a Good that can't be born. Lacan would surely not dispute Paul's charge that the Hebraic law cannot be "fulfilled." But to the extent that one lives within its borders, it nonetheless functions as a protection or barrier against something that is considerably more difficult to live with, the unmediated insistence of das Ding.

The difference between the two ethics can best be illustrated by reference to the commandment against "bearing false witness." Lacan famously suggests that this may be the cruelest commandment of all, because the subject is inseparable from the ability to lie (8I-82). But if there is a commandment against giving false testimony, it is because, in the context of Hebraic law, it is possible to lie; in Judaism there is no supposition of divine omniscience. In contrast, the notion of "sinning in the heart" elaborated in Jesus' Sermon on the Mount (Matthew 5:1-7:27), holds that to think lustful thoughts about another woman is already to commit adultery, even in the absence of an adulterous act. In this logic, it is no longer possible to fulfill the law simply by not transgressing it, or by avoiding the object it designates as abject. As a result, the law loses its function as a protective barrier. When Jesus introduces the notion of sinning in the heart, and thus the transparency of the heart to God, he suggests that it is no longer possible even to lie. In the process, he lifts the barrier against the deity that is so central to Judaism. 
Paul's polemic against the Jewish law draws upon Jesus' Sermon on the Mount (Matthew 5:1-7:27), which condenses the ten commandments to two fundamental principles: love of God and love of the neighbor. This condensation effaces the distinction between the two tablets of the Decalogue that is of such importance in Judaism, with the result that God and man are now understood as occupying the "same" space. The result is that the symbolic function of space (as the introduction of a gap) is replaced by an imaginary unity. ${ }^{29}$ There is no longer any direct theorization of what Lacan calls das Ding, nor is there any emphasis on the function of the symbolic as such, or of the role of the signifier in limiting das Ding. In fact, one could even argue that the imaginary replaces the symbolic altogether, rendering it obsolete. ${ }^{30}$

While the Mosaic law suggests that I must fear God and keep my distance from him, Jesus says that we must love God: a fearsome and even inconceivable prospect for the Jew. Now the commandments concerning the neighbor and the neighbor's things are understood not as substitutes for what is at stake in the commandments concerning God (representations that hold das Ding at a distance by evoking it in distorted form), but as fundamentally identical. Moreover, the neighbor is understood not as the uncanny, slightly menacing figure Freud describes $^{31}$ (from whom I would do well to keep my distance), but as someone with whom I'm invited to identify and to love as I love "myself." The link between the subject and the neighbor implicit in Lacan's reading of the Decalogue (where the neighbor is a displaced figure for the subject, and the neighbor's Thing is fundamentally my Thing) is brought out into the open. The result is that the "lying about evil" that defines the operation of the law is no longer allowed: the border between the subject and the neighbor, or between the subject and das Ding, is breached.

\section{Political Theology and the Question of the Border}

Despite its emphasis on God as something that must be held at a distance, Lacan's analysis of the law does not abandon the frame of political theology, but rather deploys it in a different way. Of course, it's important to Lacan's analysis that the God of the Decalogue is a negative God, defined by his absence or withdrawal from the world, and not the positive God of the miracle whose transformation of the legal order completes what was incomplete. Whereas Schmitt asserts that "all significant concepts of the modern theory of the state" are theological concepts," what Lacan finds in the Hebraic tradition is really a theory of law as distinct from the 
state (what Schmitt calls the "legal order") or from sovereign power. This theory of law is "theological" not because it derives the law from divine authority, but because it theorizes the divine in negative terms or in relation to the function of negation.

As we saw earlier, Schmitt equates the sovereign's direct intervention in a valid legal order with the transgression of the laws of nature implied in the theological concept of the miracle. Implicit in Paul's and Schmitt's respective treatments of the law is the question: where does the law belong in relation to "what is"? Both link the law to an existing order, a current state of affairs, and imagine the exception as a suspension or "transgression" of that order, one that brings about a "new kingdom." In contrast, the Hebraic tradition posits that the law itself represents a break with "what is": a break that does not bring about a "new order" by substituting one state of affairs for another, but rather carves out a negative space identified as the space of the subject: in other words, what by definition cannot be captured in the "order" of law or state, because it is located solely in speech. This is the miracle not of sovereignty, but of the signifier, which first transgresses the laws of nature by introducing a gap at the center of the real, creating a space where "something is missing." 32 The act as conceived by Paul not only rejects this logic, but involves a reinscription of the very space that was opened up by the Hebraic law, such that the "fulfillment of the law" really amounts to a canceling or undoing of this first act.

Earlier I suggested that in his claim that sovereignty is a "border concept," Schmitt's contribution to the logical problem of law as border is to claim that the border need not be written, that the sovereign exception is not of the order of a writing, but a "miracle" that is by nature unwritten and unwritable. We see something similar in Paul, who famously wrote of his own conversion experience: "I know a man in Christ who fourteen years ago was caught up to the third heaven-whether in the body or out of the body I do not know, God knows. And I know that this man was caught up into Paradise, ....and he heard things that cannot be told, which man may not utter" (2 Cor. 12:2-4). In the thrall of the event, Paul is neither in the body nor out of it, but "outside-in." 33 His conversion experience is no more "logical" than Schmitt's topology of sovereignty, but like Schmitt he makes no apologies about it. As he tells the Corinthians, "we proclaim Christ crucified, a scandal to Jews and folly to Gentiles, but to those who are called, ... Christ the power of God and the wisdom of God" (I Cor. I:22-24). Or again: "The unspiritual man does not receive the gifts of the Spirit of God, for they are folly to 
him, and he is not able to understand them because they are spiritually discerned" (I

Corinthians 2:13). There is something more than a little bit mad about these miracles, but that in no way undercuts their force or fascination: to the contrary.

No one has embraced this dimension of Paul's discourse more profoundly than Alain Badiou, who demonstrates that Paul's letters must be read not as the adumbration of a theology, but as a theory of the event. Schmitt is in many ways Paul's most faithful heir in this endeavor, demonstrating that the only response to the event of the exception is an act: an act that is necessarily as unwritable as the event itself. I would even argue that the aim of such an ethics is to demonstrate the superiority or vigor of the act with respect to the written, understood as a binding limit or normative constraint. It is surely not a coincidence, then, that the political-theological discourse of the act is invariably structured as a polemic against the written law: one that leaves us to choose between a constraining norm and an explosive act. What would it mean to posit the act in terms of the signifier, and not in terms of a violent upsurge of the real that privileges the "new" in its explosive or annihilating character, as what fulfils only by destroying what came before it? ${ }^{34}$ In this essay, l've tried to suggest that the commandment form might point toward another, more productive way of thinking about the written law: one that casts a critical eye on any account of the political sphere that upholds the unwritability of the act as its chief virtue, or attempts to reduce the function of law to the status of a secondary representation.

\footnotetext{
${ }^{1}$ Carl Schmitt, Political Theology: Four Chapters on the Concept of Sovereignty, trans. George Schwab (Cambridge: MIT Press, 1985), 12. Subsequent citations from the same text will be given as page numbers in parentheses.

${ }^{2}$ The destruction of the norm does not imply the destruction of the legal order, however. For Schmitt, "the exception remains... accessible to jurisprudence because both elements, the norm as well as the decision, remain within the framework of the juristic" (12).

${ }^{3}$ Giorgio Agamben translates Schmitt's definition of sovereignty with the formula "ecstasy-belonging," which captures very well its theological overtones. State of Exception, tr. Kevin Attell (Chicago: University of Chicago Press, 2005), 35.

${ }^{4}$ As if in emulation of this model, George W. Bush in currently in the process of annihilating the "present Jerusalem"- more broadly, the present middle east — in order to force the advent of the "Jerusalem above." ${ }^{5}$ What Paul calls "sin" is really the problem internal to language as representation. This is essentially the Platonic argument according to which a linguistic or pictorial representation is merely a copy of a copy, an empty simulacrum with no "internal resemblance" to the truth.

${ }^{6}$ This argument is developed through the opening conceit of the married woman who is no longer bound to her husband after his death: "a married woman is bound by law to her husband as long as she lives; but if her husband dies she is discharged from the law concerning the husband. Accordingly, she will be called an adulteress if she lives with another man while her husband is alive. But if her husband dies she is free from that law, and if she marries another man she is not an adulteress" (Romans 7:2-3).

${ }^{7}$ In the passage that follows, Schmitt explains: "Public order and security manifest themselves very differently in reality, depending on whether a militaristic bureaucracy, a self-governing body controlled by the spirit of
} 
commercialism, or a radical party organization decides when there is order and security and when it is threatened or disturbed. After all, every legal order is based on a decision, and also the concept of the legal order, which is applied as something self-evident, contains within it the contrast of the two distinct elements of the juristic-norm and decision. Like every other order, the legal order rests on a decision and not on a norm" (9). Conversely, one might say that the law is precisely what prevents one particular party or group from "realizing" its version of the good, which can only be introduced by a decision.

${ }^{8}$ This amounts to a foreclosure of anything like revolution or civil disobedience, the acts through which subjects claim for themselves a space in the political order.

${ }^{9}$ Walter Benjamin, "On the Concept of History," tr. Harry Zohn, in Selected Writings Volume 4, 1938-1940, ed. Howard Eiland and Michael W. Jennings. (Cambridge: Harvard University Press, 2003), 392.

${ }^{10}$ Agamben summarizes the stakes of Benjamin's critique in the following terms: "Germany found itself technically in a situation of sovereign dictatorship, which should have led to the definitive abolition of the Weimar Constitution and the establishment of a new constitution, whose fundamental characteristics Schmitt strove to define in a series of articles between 1933 and 1936. But what Schmitt could in no way accept was that the state of exception be wholly confused with the rule. In Dictatorship, he had already stated that arriving at a correct concept of dictatorship is impossible as long as every legal order is seen 'only as a latent and intermittent dictatorship.' To be sure, Political Theology unequivocally acknowledged the primacy of the exception, insofar as it makes the constitution of the normal sphere possible; but if, in this sense, the rule 'lives only by the exception,' what then happens when exception and rule become undecidable? From Schmitt's perspective, the functioning of the juridical order ultimately rests on an apparatus - the state of exception - whose purpose is to make the norm applicable by temporarily suspending its efficacy. When the exception becomes the rule, the machine can no longer function. In this sense, the undecidability of norm and exception formulated in the eighth thesis puts Schmitt's theory in check. Sovereign decision is no longer capable of performing the task that Political Theology assigned it: the rule, which now coincides with what it lives by, devours itself" (State of Exception, 58).

${ }^{11}$ Paul shows how what Benjamin calls the "state of exception become the rule" is implicit in the political theology that grounds Schmitt's account of the exception, and belies Schmitt's claims that the suspension of the constitution can be merely temporary. In wondering about a state of exception that becomes the rule, Benjamin is really zeroing in on something that is laid bare by Paul, but passed over by Schmitt: the fundamental and irreparable antinomy between the spirit and the letter of the law, or between the sovereign exception and the constitutional order. Whereas Schmitt cannot imagine a conflation of the state of exception with the rule, Paul makes clear that one can access the Good only if the "state of exception becomes the rule," if the Good is accessed through the suspension of the law.

${ }^{12}$ Commenting this passage, Giorgio Agamben explains that "Schmitt, in his tenacious critique of the legal state [Stato di diritto], gives the name 'fictitious' to a state of exception that would be regulated by law, with the aim of guaranteeing some degree of individual rights and liberties. Consequently, he forcefully denounces the Weimar jurists' inability to distinguish between the merely factual action of the president of the Reich under Article 48 and a procedure regulated by law. Benjamin once again reformulates the opposition in order to turn it back against Schmitt. Now that any possibility of a fictitious state of exception - in which exception and normal conditions are temporally and locally distinct - has collapsed, the state of exception 'in which we live' is real and absolutely cannot be distinguished from the rule. Every fiction of a nexus between violence and law disappears here: there is nothing but a zone of anomie, in which violence works without juridical clothing of any kind. The attempt of state power to annex anomie through the state of exception is unmasked by Benjamin for what it is: a fictio iuris par excellence, which claims to maintain the law in its very suspension as force-of-taw" (Agamben 59, translation modified).

${ }^{13}$ In his book on the Trauerspiel, Benjamin writes "Spirit manifests itself as a capacity to exercise dictatorship": the dismantling of the law introduces the possibility of a "dictatorship of spirit," a "force of law" that operates without regard for law, without limit. The Origin of German Tragic Drama, tr. George Steiner (London: Verso, 1998), 98.

${ }^{14}$ The Seminar of Jacques Lacan Book VII: The Ethics of Psychoanalysis, ed. Jacques-Alain Miller, tr. Dennis Porter. (New York: Norton, 1992), 70. Subsequent citations from the same text will be given as page numbers in parentheses.

15 "Freud is telling us the same thing as Saint Paul, namely, that what governs us on the path of our pleasure is no Sovereign Good, and that moreover, beyond a certain limit, we are in a thoroughly enigmatic position relative to that which lies within das Ding, because there is no ethical rule which acts as a mediator between our pleasure and its real rule" (96). For emphasis Lacan cites the words of Jesus: "Why do you speak to me of good? Who knows 
what is good? Only He, He who is beyond, our Father, knows what is good. And He told you, Do this, Do that, Don't go any further."

${ }^{16}$ Clinically, the elaboration of the signifying chain under transference offers some respite from the drive by partially binding this unbound energy, lowering the tension associated with the insistence of the real.

${ }^{17}$ With respect to the Lacan quote in note 15 , which underscores that there is nothing to act as a mediator between our pleasure and its rule, one could say that for Schmitt the sovereign attempts to "act as a mediator" where the law fails to do so, to bridge this gap.

${ }^{18}$ In the passage cited earlier on the "general good," Schmitt argues that the legal order rests on an act, and makes this act synonymous with decision: in other words, the sovereign has to inscribe the good in the legal order, to integrate or place at the center of the legal order what Lacan holds to be antithetical to the function of law, at the center only as excluded.

${ }^{19}$ It is not surprising, therefore, that states of exception are so often marked by the resurgence of the real, the violent or predatory practices that under "normal" circumstances are prohibited by law: illegal detention and surveillance, torture and killing by the police or military, "ethnic cleansing" and rape as means of population control, and so forth.

${ }^{20}$ By means of condensation and displacement, or the rhetorical registers of metaphor and metonymy.

${ }^{21}$ Lacan asserts that das Ding is "something only a representation can represent" (7I). He then explains, "Do not look upon that as a simple pleonasm, for 'represent' and 'representation' here are two different things, as the term Vorstellungsrepräsentanz indicates. It is a matter of that which in the unconscious represents, in the form of a sign, representation as a function of apprehending - of the way in which every representation is represented insofar as it evokes the good that das Ding brings with it" (7I-72).

${ }^{22}$ The clinic of the dream reveals that the logic of "lying about evil" characterizes the action of the signifier as such, which transforms disturbing psychic content through condensation and displacement and so allows it to be represented; this representation in turn functions to bind the drive energy. The example concerns the status of representation as a signifier, and not as an image.

${ }^{23}$ The fetish substitutes for something that doesn't even exist, that is of the order of a hallucination. But it substitutes for the hallucinated object with the purpose of disavowing castration: castration is therefore in the place of das Ding, and the fetish as maternal phallus "represents" it in the mode of disavowal.

${ }^{24}$ In this respect Lacan's account of the law as "lying about evil" also accords with Benjamin's invocation of the "juridical clothing" of the letter of the law as a necessary obstacle to the "state of exception become the rule." If, as Schmitt maintains, the law were simply the representation of an authority that is not based on law (the sovereign decision, the transcendent "Law of God"), then it would not be necessary. But the notion of "juridical clothing" supposes another understanding of the law's function: to separate or erect a boundary between exception and rule, between spirit and letter.

${ }^{25}$ Walter Benjamin makes a similar argument in "Critique of Violence," when he asserts that historically no major legal system prior to the modern era has ever imposed a sanction for lying. Like Lacan, Benjamin emphasizes the function of the lie as a boundary or limit that encloses a space in which subjective life is possible. But in the abuses of legal power that Benjamin identifies with the modern police state, the right of the subject to lie comes under attack: this barrier against the power of the state is eroded through such practices as surveillance, wiretapping, and the use of torture to extract testimony. "Critique of Violence," in Selected Writings Volume I: 1913-1926, ed. Marcus Bullock and Michael W. Jennings (Cambridge: Belknap/Harvard, 1996), 244-245.

${ }^{26}$ Kenneth Reinhard and Julia Reinhard Lupton, "The Subject of Religion: Lacan and the Ten Commandments," diacritics 33:2, 83. They also link the commandment to the emergence of the subject: "the commandment begins to move the Decalogue away from a discourse of pure alienation, since the gap introduced by the Sabbath is what allows for the possibility of subjectivization. The subject of religion, that is, only emerges in the decompletion of the symbolic universe, through the positive addition to the cosmos of an instance of negation, of suspended activity. In this moment of ar-rest, the subject comes forward as the bearer of the lack that has engendered him, in relation to an as yet unrealized positivity beyond or left over by lack, as its remainder or 'rest."'

${ }^{27}$ In the context of the ancient Mediterranean, YHWH is the only God who is not part of his own creation. Martin Buber suggests that the defining characteristic of early Judaism is its break with the worship of nature, symbolized by the gap introduced into the solar and lunar cycles of day and month by the commandment to honor the Sabbath day. Martin Buber, Moses (New York: Harper \& Row, 1958), 126.

${ }^{28}$ As a mediated representation of the Good, the law provides an opportunity to sin, which profits from the lying or deception that is proper to the law in order to lead us astray. The result is a fall into a world of mediated representations, sinful images and objects of covetousness that distract us from the Good. 
${ }^{29}$ One effect of this shift is that while spatiality and distance are of primary importance in Judaism, the spatial configurations of Jewish worship are gradually displaced in Christianity in favor of transcendent or temporal configurations: the "Jerusalem above" vs. the "present Jerusalem," the spatially unspecific "brotherhood," the body as a "temple of the holy spirit" in which the divine is fully present, and so forth.

${ }^{30}$ The sign of this replacement is that the commandments of the first tablet essentially disappear in Christian observance, beginning with the commandment against making idols. Not only is it now possible to represent God, but images come to occupy a central place in Christian iconography. This shift is in turn intimately linked to the theory of sovereignty. Where the logic of the commandments specifically precludes the law being "embodied" or given form, Schmitt's decisionism - like Paul's account of the fulfillment of the law-gives pride of place to the imaginary incarnation of the law, and suggests that the word may indeed be "made flesh."

${ }^{31}$ See in particular Chapter V of Civilization and its Discontents, tr. James Strachey (New York: W.W. Norton \& Co., 1961), 64-74.

32 This gap is understood not only as the place where the norms do not apply (or where representation does not function), but as a place where "something is missing," a space of negation.

${ }^{33}$ Brad Zukovic has analyzed this passage as an example of the rhetorical-topological figure he calls "temporal synechdoche." "Four Ways into a Vortex: Metaphor and Machine Logic," forthcoming in (a): the journal of culture and the unconscious.

${ }^{34}$ In Schmitt's exemplary formulation, "The exception is more interesting than the rule. The rule proves nothing; the exception proves everything: It confirms not only the rule but also its existence, which derives only from the exception. In the exception the power of real life breaks through the crust of a mechanism that has become torpid by repetition" (I5). 